\title{
EFFECT OF WEANING IRRIGATION DATES AND SPRAYING WITH DROUGHT TOLERANCE MATERIALS ON GROWTH AND PRODUCTIVITY OF VARIETY COTTON GIZA 94.
}

\author{
M.A. Emara, Amal S. Abdel-Aal and El-D. El-D. Deshish \\ Department of Agronomy, Cotton Research Institute, AgriculturalResearch Center, \\ Giza, Egypt. \\ Received: Dec. 6, 2019 \\ Accepted: Dec. 13, 2020
}

\begin{abstract}
Two field experiments were carriedout in Sakha Agricultural Research Station at Kafr El-Sheikh Governorate, Egypt, during the growing seasons 2018 and 2019 to study the effect of weaning irrigation dates and spraying with drought tolerance materials on growth, earliness, yield and its components and fiber quality of cotton for Giza 94 cotton variety belonging to (Gossypium barbadense, L). The experimental design was a split plot with four replications. The main plots involved the four weaning irrigation dates (last irrigation dates) (control, after 4 irrigation, after 5 irrigation and after 6 irrigation after the first irrigation date), and the sub plots included drought tolerance materials (control without treatment, sprayed with K-Silicate, sprayed with K-Acetate and sprayed with Glycine betaine). The obtained results revealed that weaning irrigation after 4 irrigation from planting had significantly increased earliness \% in both seasons. While, significantly decreased the days to first flower, days to first open boll in the both seasons compared with the other treatments. While, had significant effect on no. of open bolls/plant, boll weight and seed cotton yield/fed., were insignificantly affected seed index and lint \% in both seasons. Spraying drought tolerance materials had a significant effect on plant height in both seasons, while did not exhibit significant effect on, first fruiting node, days to first flower, days to first open boll and earliness \%.Yield and yield components traits were significantly affected by drought tolerance materials treatments except seed index and lint \% in both seasons. Sprayed with Glycine betaine significantly increased no. of open bolls/plant, boll weight and seed cotton yield/fed. The weaning irrigation dates, spraying drought tolerance materials and the interaction between them did not exhibit significant effect on all fiber properties under study.It could be concluded that using weaning irrigation after six irrigation from planting and spraying drought tolerance materials with Glycine betaine at $600 \mathrm{~g} / \mathrm{fed}$. gave high productivity of cotton Giza 94.
\end{abstract}

Key words: Cotton, Weaning Irrigation, Potassium Silicate, Potassium Acetate Glycine Betaine, Growth, Yield, Fiber Quality.

\section{INTRODUCTION}

Water management is a primary factor controlling cotton plant growth. Water is essential for cell turgidity which is related to photosynthesis, growth of cells, tissues and organs (Reddi and Reddi, 1995). Water plays a key role in achieving higher yields because it is an important constituent of plants and plays a vital role in many metabolic processes.
It increases leaf production and expansion rate, leaf area duration which affects radiation interception and consequently contributes towards final dry matter production (Watson, 1952). Water need of the crop is the prime consideration to decide the time and amount of irrigation. Irrigation water applied less or more than the optimum requirement of a crop adversely affects the yield. 
In Egypt, the date of last irrigation has a great effect on the yield of seed cotton. The date of irrigation termination in cotton field has a great role in determining the yield and lint characters. Therefore, the beneficial effects of applying the last irrigation in proper time are laying in maturation of late bolls without promotion new growth (Ray and Hazlitt, 1960). At the time of last irrigation, all bolls have been set, vegetative growth is limited and the majority of carbohydrates produced are used to satisfy boll demands (CSD, 2010).The date of the final irrigation depends on the amount of available moisture in the root zone, the amount of water thatcan be placed in the root zone by the irrigation and the remaining water use between the date of the last irrigation and crop maturity.

Sawires (1976) found that irrigation through the late part of the season had no effect on final plant height, total bolls/plant and seed index, while it increased no. of fruiting branches, boll weight, seed cotton yield and lint percentage. Abdel-Aal and Emara (2014) mentioned that the final irrigation after 150 days from planting produced the highest seed cotton yield/fed. While, yield components increased in favour of final irrigation after 165 days from planting. Makram and Abo-Nour (1995) cleared that last irrigation treatments had insignificant effect on the yield components and yield of seed cotton Giza $\mathbf{8 0}$ for early and late sowings.

Abdel-Aal (1996) revealed that the last irrigation till the $12^{\text {th }}$ week of flowering significantly increased monopodial branches, while retarded maturation as expressed by either higher no. of days to the first open boll or lower earliness percentage. Also, there was an insignificant superiority for seed cotton yield with ending irrigation at the $10^{\text {th }}$ week of flowering. As for late sowing, the last irrigation significantly increased final plant height and sympodial branches, no. of open bolls, boll weight and seed cotton yield. Abdel-Malak and Makram (1996) revealed that the timing of last irrigation had insignificant effect on final plant height and no. of fruiting branches/plant while delaying last irrigation increased significantly no. of open bolls/plant, boll weight, seed cotton yield/plant and /fed. were increased in favour of last irrigation at $11^{\text {th }}$ week of flowering for early sowing and $8^{\text {th }}$ or $10^{\text {th }}$ week of flowering for late sowing while, yield earliness was increased significantly in favour of last irrigation $9^{\text {th }}$ and $8^{\text {th }}$ weeks of flowering for early and late sowings, respectively. Ali et al., (1997) indicated that final plant height, no. of sympodia/plant, boll weight, and no. of open bolls/plant and seed cotton yield in kentar/fed. for both cultivars tended to increase as continuing irrigation till $11^{\text {th }}$ and $12^{\text {th }}$ weeks of beginning of flowering for early and late sowings, respectively. Tennakoon and Milroy (2003) verified that irrigation up to 95 days after the seedling emergence contributed towards an increase in crop yield; the largest increase occurred when the last irrigation was applied on the 65th day; and 80th day.

Potassium $(\mathrm{K})$ is an important nutrient that has favorable effects on the metabolism of nucleic acids, proteins, vitamins and growth substances. Furthermore, $\mathrm{K}$ plays an important role in the translocation of photsynthates from sources to sinks (Morteza et al., 2005). Many studies have shown increased yield and cotton productivity in response to potassium fertilization as reported by Gomaa et al., (2014) and Emara (2014). Many studies have shown increased yield and cotton productivity in response to potassium fertilization as reported by Basbag (2008), Temz et al. (2009) and Abou-Zaid et al. (2013) stated that added potassium fertilizer as soil or foliar 
application improved growth, yield and its components of cotton plant.

Glycine betaine also protects physiological processes such as photosynthesis and protein synthesis from the result of water deficit and other stresses (Meek et al., 2003). Glycine betaine has been exogenously applied to a variety of crops in an effort to improve stress tolerance and yield. Some of crops include cotton (Gorham and Jokinen, 1998). Results varied, however, and appeared to depend on numerous factors such as type of crop, timing and rate of application and environmental conditions. In soybeen, exogenous foliar applications of glycine betaine decreased transpiration, increased leaf conductance, improved photosynthetic activity and increased leaf area, but an overall increase in yield between treated and control plants was not observed (Agbomaet al., 1997). Alia (2003) and Alia and Emara (2008), found that glycine betaine dose and time of application had highly significant effects increased in no. of bolls and flowers/plant and seed cotton yield/feddan. On the other hand, fiber properties were insignificantly affected. On contrary, Meek et al. (2003), reported that endogenous glycine betaine concentrations were significantly higher in water-deficit stressed plants, but were unaffected by foliar application of glycine betaine.

Our objectives were to determine the influence of the timing of last irrigation dates and spraying with drought tolerance materials on growth, yield and its components and fiber properties of Egyptian cotton Giza 94.

\section{MATERIALS AND METHODS}

Two field experiments were conducted at Sakha Agricultural Research Station at Kafr El-Sheikh Governorate, Egypt, during the growing seasons 2018 and 2019 to study the effect of weaning irrigation dates and spraying with drought tolerance materials on growth, earliness, yield and its components and fiber quality of cotton for the of variety cotton Giza 94. The experimental design was a split plot with four replications. The main plots involved the weaning irrigation dates (last irrigation dates) (control (after 8 irrigation), after 4 irrigation, after 5 irrigation and after 6 irrigation after the first irrigation date), and the sub plots included spraying with drought tolerance materials (control without treatment, sprayed with KSilicate, sprayed with K-Acetate and sprayed with Glycine betaine).Sprayed three times (at squaring, floret initiation and two weeks after flowering). Characterized the new promising hybrid cotton (Giza $86 \times 10229$ ) are showed in Table (1).

The sub-plot size was $24 \mathrm{~m}^{2}$, including 8 rows, $60 \mathrm{~cm}$ wide and $5 \mathrm{~m}$ long with hills $25 \mathrm{~cm}$ apart in both seasons. Cottonseeds were sown after two cuts of Egyptian clover Barseem (Trifolium alexandrinum, L.) in 2018 and 2019 seasons. Soil samples was taken in the two seasons before planting to estimate the soil characters using the standard methods as described by Chapman and Parker (1981). The results are shown in Table (2).

Seedlings were thinned at 2 plants/hill, phosphorus fertilizer as ordinary superphosphate $\left(15.5 \% \quad \mathrm{P}_{2} \mathrm{O}_{5}\right)$ at the rate of $22.5 \mathrm{~kg} \mathrm{P}_{2} \mathrm{O}_{5} / \mathrm{fed}$ incorporated during seed bed preparation. Nitrogen fertilizer in the form of ammonium nitrate $(33.5 \% \mathrm{~N})$ at the rate of $60 \mathrm{~kg} \mathrm{~N} / \mathrm{fedwas}$ applied in two equal doses, immediately before first and second irrigations. Potassium sulphate $\left(48 \% \mathrm{~K}_{2} \mathrm{O}\right)$ at the rate of $24 \mathrm{~kg} \mathrm{~K} \mathrm{~K}_{2} \mathrm{O} / \mathrm{fed}$ was side-dressed in a single dose at thinning before the second irrigation 
Standard agricultural practices were followed throughout the growing seasons. All samples were taken at random in order to study the traits. At harvest, 6 guarded plants were randomly taken from the central row of each plot to determine plant height at harvest, no. of fruiting branches/plant, first fruiting node, no. of days to the first flower, no. of days to the first open boll, boll weight (g), no. of bolls/plant, lint \% and seed index (g). Seed cotton yield (ken./fed.) was estimated as the weight of seed cotton yield by kilogram picked from the five middle rows in plot collected from two picks, then converted to yield/fed. inkentar $($ Kentar $=157.5 \mathrm{~kg}$.). Earliness \% was determined as percent of seed cotton yield of first pick to total seed cotton yield. Samples of lint cotton under different treatments were tested at the C.R.I. laboratories to determine fiber properties according to A.S.T.M. (2012).Analysis of variance of the obtained data of each season wasperformed. The measured variables were analysed by ANOVA using $M$ Stat-C statistical package (Freed, 1991). Mean comparisons were done using least significant differences (L.S.D) method at $5 \%$ level of probability to compare differences between the means (Snedecor and Cochran, 1988).

Table (1): Characterized the cotton variety Giza 94.

\begin{tabular}{|c|c|}
\hline Genotype name & Giza 94 cotton variety \\
\hline Species & Barbadense. \\
\hline Category & Long staple and extra fine. \\
\hline Pedigree & Crossing between G86 x 10229 \\
\hline Characteristics & $\begin{array}{l}\text { Long staple characterized by high yielding, early maturity, } \\
\text { resistance to Fuzariam and high lint (\%). }\end{array}$ \\
\hline $\begin{array}{l}\text { Botanical } \\
\text { distinguishing } \\
\text { characters }\end{array}$ & $\begin{array}{l}\text { The stem has a medium length with polygon shape also has green } \\
\text { color mixed by dim red with medium length internodes. The leaves } \\
\text { have palmate shape with large size with no deep lobes and leather } \\
\text { fell. The node of the first fruiting branch ranged from } 8-9 \text {. A flower } \\
\text { petal has tubular shape. The boll size is large and pyramid shape } \\
\text { with drawn summit. Seed is big-sized and the fuzz covers about } \\
\text { fuzz less to } 1 / 4 \text { from the whole size and fuzz color is gray-greenish }\end{array}$ \\
\hline Hybrid bred by & $\begin{array}{l}\text { Breeding Res. Section, Cotton Res. Inst., Agric. Res. Center, } \\
\text { Giza, Egypt. }\end{array}$ \\
\hline
\end{tabular}

Table (2): Mechanical and chemical analysis of the experiment soil in 2018 and 2019 seasons.

\begin{tabular}{|c|c|c|c|c|c|c|c|c|}
\hline \multirow{2}{*}{ Season } & \multirow{2}{*}{ Texture } & $\mathrm{pH}$ & $\begin{array}{c}\text { Organic } \\
\text { Matter (\%) }\end{array}$ & $\begin{array}{c}\mathrm{EC}(\mathrm{m} \\
\mathrm{mhos} / \mathrm{cm})\end{array}$ & $\begin{array}{c}\text { Bicarbonate } \\
(\%)\end{array}$ & \multicolumn{3}{|c|}{$\begin{array}{c}\text { Available elements } \\
(\mathrm{ppm})\end{array}$} \\
\cline { 7 - 9 } & & & & & $\mathrm{N}$ & $\mathrm{P}$ & $\mathrm{K}$ \\
\hline 2018 & Clay loam & 8.1 & 1.4 & 0.44 & 1.27 & 25.3 & 14.8 & 291 \\
\hline 2019 & Clay loam & 8.4 & 1.48 & 0.57 & 1.43 & 24.8 & 13.2 & 244 \\
\hline
\end{tabular}




\section{RESULTS AND DISCUSSION}

The results of growth attributes, earliness parameters, yield and its components and fiber properties as affected by weaning irrigation dates and spraying with drought tolerance materials on growth, earliness, yield and its components and fiber quality of cotton for the of variety cotton Giza 94 during 2018 and 2019 seasons are shown in Tables (3 to 5).

Table (3): Effect of weaning irrigation dates and spraying with drought tolerance materials and its interaction on growth and earliness traits of cotton during 2018 and 2019 seasons.

\begin{tabular}{|c|c|c|c|c|c|c|c|c|c|c|c|c|c|}
\hline \multirow{2}{*}{\multicolumn{2}{|c|}{ Treatments }} & \multicolumn{4}{|c|}{ Growth traits } & \multicolumn{8}{|c|}{ Earliness traits } \\
\hline & & \multicolumn{2}{|c|}{$\begin{array}{c}\text { Plant height } \\
\text { at harvest } \\
(\mathrm{cm})\end{array}$} & \multicolumn{2}{|c|}{$\begin{array}{l}\text { No. of } \\
\text { fruiting } \\
\text { branches } \\
\text { /plant }\end{array}$} & \multicolumn{2}{|c|}{$\begin{array}{l}\text { First } \\
\text { fruiting } \\
\text { node }\end{array}$} & \multicolumn{2}{|c|}{$\begin{array}{l}\text { Days to the } \\
\text { first flower }\end{array}$} & \multicolumn{2}{|c|}{$\begin{array}{c}\text { Days to the } \\
\text { first open } \\
\text { boll }\end{array}$} & \multicolumn{2}{|c|}{ Earliness \% } \\
\hline $\begin{array}{c}\text { irrigation } \\
\text { dates }(A)\end{array}$ & $\begin{array}{l}\text { tolerance } \\
\text { materials } \\
\text { (B) }\end{array}$ & 2018 & 2019 & 2018 & 2019 & 2018 & 2019 & 2018 & 2019 & 2018 & 2019 & 2018 & 2019 \\
\hline \multirow{4}{*}{ Cont. } & Cont. & 155.0 & 168.6 & 14.4 & 17.6 & 6.5 & 6.4 & 76.7 & 77.3 & 125.4 & 125.6 & 77.4 & 77.2 \\
\hline & K-Silicate & 152.0 & 164.3 & 14.7 & 17.8 & 6.4 & 6.3 & 76.3 & 77.0 & 125.1 & 125.4 & 77.9 & 77.2 \\
\hline & K-Acetate & 151.0 & 163.3 & 14.7 & 17.8 & 6.4 & 6.3 & 76.3 & 77.1 & 125.1 & 125.4 & 77.8 & 77.4 \\
\hline & GB & 151.0 & 161.3 & 14.6 & 17.7 & 6.5 & 6.3 & 76.2 & 76.9 & 125.0 & 125.7 & 77.5 & 77.2 \\
\hline \multicolumn{2}{|c|}{ Mean } & 152.3 & 164.4 & 14.6 & 17.7 & 6.4 & 6.3 & 76.4 & 77.1 & 125.2 & 125.5 & 77.6 & 77.3 \\
\hline \multirow{4}{*}{$\begin{array}{c}\text { after } 4 \\
\text { irrigation }\end{array}$} & Cont. & 146.0 & 163.7 & 13.8 & 16.7 & 6.4 & 6.3 & 74.0 & 75.4 & 124.2 & 124.3 & 78.8 & 78.9 \\
\hline & K-Silicate & 145.3 & 161.7 & 14.0 & 16.8 & 6.3 & 6.3 & 73.8 & 75.2 & 123.4 & 124.0 & 78.9 & 79.0 \\
\hline & K-Acetate & 145.7 & 160.0 & 14.0 & 16.9 & 6.4 & 6.4 & 74.0 & 75.2 & 123.5 & 123.9 & 79.1 & 79.1 \\
\hline & GB & 145.0 & 156.6 & 14.0 & 16.9 & 6.4 & 6.3 & 73.8 & 75.1 & 123.4 & 123.7 & 79.0 & 79.2 \\
\hline \multicolumn{2}{|c|}{ Mean } & 145.5 & 160.5 & 13.9 & 16.9 & 6.4 & 6.3 & 73.9 & 75.2 & 123.6 & 124.0 & 78.9 & 79.1 \\
\hline \multirow{4}{*}{$\begin{array}{c}\text { after } 5 \\
\text { irrigation }\end{array}$} & Cont. & 147.0 & 157.7 & 14.1 & 17.0 & 6.4 & 6.4 & 74.2 & 76.1 & 124.2 & 124.6 & 78.2 & 78.2 \\
\hline & K-Silicate & 146.0 & 158.0 & 14.2 & 17.1 & 6.4 & 6.3 & 74.0 & 75.7 & 123.8 & 124.1 & 78.3 & 78.3 \\
\hline & K-Acetate & 145.0 & 155.7 & 14.2 & 17.1 & 6.5 & 6.4 & 74.0 & 75.9 & 123.5 & 123.9 & 78.5 & 78.4 \\
\hline & GB & 145.7 & 155.3 & 14.1 & 17.4 & 6.3 & 6.3 & 73.9 & 75.2 & 123.5 & 123.8 & 78.3 & 78.4 \\
\hline \multicolumn{2}{|c|}{ Mean } & 145.9 & 156.7 & 14.1 & 17.2 & 6.4 & 6.4 & 74.0 & 75.7 & 123.7 & 124.1 & 78.3 & 78.3 \\
\hline \multirow{4}{*}{$\begin{array}{c}\text { after } 6 \\
\text { irrigation }\end{array}$} & Cont. & 151.3 & 165.3 & 14.4 & 17.4 & 6.4 & 6.3 & 76.7 & 77.4 & 125.0 & 125.3 & 78.0 & 77.4 \\
\hline & K-Silicate & 150.0 & 163.7 & 14.6 & 17.7 & 6.3 & 6.3 & 76.4 & 77.3 & 124.7 & 125.1 & 78.3 & 77.5 \\
\hline & K-Acetate & 149.7 & 163.0 & 14.5 & 17.7 & 6.3 & 6.3 & 76.5 & 77.4 & 124.6 & 124.9 & 78.4 & 78.1 \\
\hline & GB & 149.7 & 162.7 & 14.6 & 17.7 & 6.3 & 6.3 & 75.9 & 76.9 & 124.8 & 125.1 & 78.3 & 78.2 \\
\hline \multicolumn{2}{|c|}{ Mean } & 150.2 & 163.6 & 14.5 & 17.6 & 6.3 & 6.3 & 76.4 & 77.3 & 124.8 & 125.1 & 78.2 & 77.8 \\
\hline \multirow{4}{*}{$\begin{array}{l}\text { General } \\
\text { mean of } \\
\text { (B) }\end{array}$} & Cont. & 149.8 & 163.8 & 14.2 & 17.2 & 6.4 & 6.4 & 75.4 & 76.5 & 124.7 & 125.0 & 78.1 & 77.9 \\
\hline & K-Silicate & 148.3 & 161.9 & 14.4 & 17.4 & 6.4 & 6.3 & 75.1 & 76.3 & 124.3 & 124.6 & 78.4 & 78.0 \\
\hline & K-Acetate & 147.8 & 160.5 & 14.4 & 17.4 & 6.4 & 6.4 & 75.2 & 76.4 & 124.2 & 124.5 & 78.4 & 78.3 \\
\hline & GB & 147.8 & 159.0 & 14.3 & 17.4 & 6.4 & 6.3 & 75.0 & 76.0 & 124.2 & 124.6 & 78.3 & 78.2 \\
\hline \multirow{3}{*}{$\begin{array}{l}\text { LSD at } \\
0.05 \text { for }\end{array}$} & A & 2.24 & 2.08 & 0.41 & 0.22 & N.S & N.S & 0.20 & 0.29 & 0.28 & 0.38 & 0.28 & 0.22 \\
\hline & B & 1.02 & 1.21 & N.S & N.S & N.S & N.S & N.S & N.S & N.S & N.S & N.S & N.S \\
\hline & $A \times B$ & N.S & N.S & N.S & N.S & N.S & N.S & N.S & N.S & N.S & N.S & 0.72 & 0.97 \\
\hline
\end{tabular}


M.A.Emara, et al.,

Table (4): Effect of weaning irrigation dates and spraying with drought tolerance materials and its interaction on yield and yield components of cotton during 2018 and 2019 seasons.

\begin{tabular}{|c|c|c|c|c|c|c|c|c|c|c|c|}
\hline \multirow{2}{*}{\multicolumn{2}{|c|}{ Treatments }} & \multicolumn{10}{|c|}{ Yield and yield components } \\
\hline & & \multicolumn{2}{|c|}{$\begin{array}{c}\text { No. of open } \\
\text { bolls }\end{array}$} & \multicolumn{2}{|c|}{ Boll weight } & \multicolumn{2}{|c|}{ Seed index } & \multicolumn{2}{|c|}{ Lint \% } & \multicolumn{2}{|c|}{$\begin{array}{l}\text { Seed cotton } \\
\text { yield/fed. }\end{array}$} \\
\hline $\begin{array}{c}\text { weaning } \\
\text { irrigation } \\
\text { dates(A) }\end{array}$ & $\begin{array}{l}\text { Drought } \\
\text { tolerance } \\
\text { materials } \\
\text { (B) }\end{array}$ & 2018 & 2019 & 2018 & 2019 & 2018 & 2019 & 2018 & 2019 & 2018 & 2019 \\
\hline \multirow{4}{*}{ Cont. } & Cont. & 15.6 & 19.6 & 2.77 & 2.78 & 11.36 & 11.36 & 39.86 & 39.85 & 8.79 & 9.90 \\
\hline & K-Silicate & 15.7 & 19.6 & 2.80 & 2.81 & 11.37 & 11.35 & 39.89 & 39.89 & 8.96 & 10.09 \\
\hline & K-Acetate & 15.7 & 19.7 & 2.80 & 2.82 & 11.36 & 11.35 & 39.89 & 39.89 & 8.90 & 10.03 \\
\hline & GB & 15.8 & 19.9 & 2.81 & 2.84 & 11.35 & 11.37 & 39.88 & 39.89 & 9.01 & 10.13 \\
\hline \multicolumn{2}{|c|}{ Mean } & 15.7 & 19.7 & 2.79 & 2.82 & 11.36 & 11.36 & 39.88 & 39.88 & 8.91 & 10.04 \\
\hline \multirow{4}{*}{$\begin{array}{c}\text { after } 4 \\
\text { irrigation }\end{array}$} & Cont. & 15.3 & 19.3 & 2.76 & 2.78 & 11.30 & 11.37 & 39.82 & 39.84 & 8.61 & 9.68 \\
\hline & K-Silicate & 15.5 & 19.4 & 2.76 & 2.79 & 11.32 & 11.35 & 39.83 & 39.85 & 8.70 & 9.78 \\
\hline & K-Acetate & 15.5 & 19.6 & 2.77 & 2.78 & 11.32 & 11.36 & 39.83 & 39.85 & 8.63 & 9.82 \\
\hline & GB & 15.5 & 19.6 & 2.78 & 2.80 & 11.31 & 11.37 & 39.82 & 39.83 & 8.72 & 9.91 \\
\hline \multicolumn{2}{|c|}{ Mean } & 15.5 & 19.5 & 2.77 & 2.79 & 11.31 & 11.36 & 39.83 & 39.84 & 8.66 & 9.80 \\
\hline \multirow{4}{*}{$\begin{array}{c}\text { after } 5 \\
\text { irrigation }\end{array}$} & Cont. & 15.5 & 19.7 & 2.76 & 2.77 & 11.34 & 11.35 & 39.86 & 39.86 & 8.67 & 9.87 \\
\hline & K-Silicate & 15.6 & 19.6 & 2.76 & 2.78 & 11.35 & 11.36 & 39.84 & 39.86 & 8.73 & 9.90 \\
\hline & K-Acetate & 15.7 & 19.9 & 2.76 & 2.78 & 11.35 & 11.35 & 39.84 & 39.87 & 8.83 & 10.05 \\
\hline & GB & 15.8 & 20.1 & 2.78 & 2.80 & 11.35 & 11.35 & 39.85 & 39.86 & 8.88 & 10.22 \\
\hline \multicolumn{2}{|c|}{ Mean } & 15.6 & 19.8 & 2.77 & 2.79 & 11.35 & 11.35 & 39.85 & 39.87 & 8.78 & 10.01 \\
\hline \multirow{4}{*}{$\begin{array}{c}\text { after } 6 \\
\text { irrigation }\end{array}$} & Cont. & 15.6 & 19.8 & 2.77 & 2.81 & 11.36 & 11.35 & 39.88 & 39.89 & 8.81 & 10.06 \\
\hline & K-Silicate & 15.7 & 20.3 & 2.79 & 2.81 & 11.37 & 11.35 & 39.88 & 39.89 & 8.91 & 10.23 \\
\hline & K-Acetate & 15.8 & 20.8 & 2.78 & 2.82 & 11.37 & 11.35 & 39.87 & 39.89 & 8.88 & 10.21 \\
\hline & GB & 16.0 & 20.2 & 2.81 & 2.84 & 11.37 & 11.36 & 39.87 & 39.88 & 9.05 & 10.24 \\
\hline \multicolumn{2}{|c|}{ Mean } & 15.8 & 20.3 & 2.79 & 2.82 & 11.37 & 11.35 & 39.87 & 39.89 & 8.79 & 10.18 \\
\hline \multirow{4}{*}{$\begin{array}{l}\text { General } \\
\text { mean of } \\
\text { (B) }\end{array}$} & Cont. & 15.5 & 19.6 & 2.76 & 2.79 & 11.34 & 11.36 & 39.86 & 39.86 & 8.72 & 9.88 \\
\hline & K-Silicate & 15.7 & 19.7 & 2.78 & 2.80 & 11.35 & 11.35 & 39.86 & 39.87 & 8.82 & 10.00 \\
\hline & K-Acetate & 15.7 & 19.9 & 2.78 & 2.80 & 11.35 & 11.35 & 39.86 & 39.88 & 8.81 & 10.03 \\
\hline & GB & 15.8 & 20.2 & 2.79 & 2.82 & 11.35 & 11.36 & 39.85 & 39.87 & 8.91 & 10.13 \\
\hline \multirow{3}{*}{$\begin{array}{l}\text { LSD at } \\
0.05 \text { for }\end{array}$} & A & 0.01 & 0.43 & 0.01 & 0.01 & N.S & N.S & N.S & N.S & 0.12 & $0.1^{r}$ \\
\hline & B & 0.21 & 0.19 & 0.02 & 0.01 & N.S & N.S & N.S & N.S & 0.09 & 0.1 \\
\hline & $A \times B$ & 0.39 & 0.22 & 0.04 & 0.03 & N.S & N.S & N.S & N.S & 0.19 & 0.28 \\
\hline
\end{tabular}


Table (5): Effect of weaning irrigation dates and spraying with drought tolerance materials and its interaction on fiber properties of cotton during 2018 and 2019 seasons.

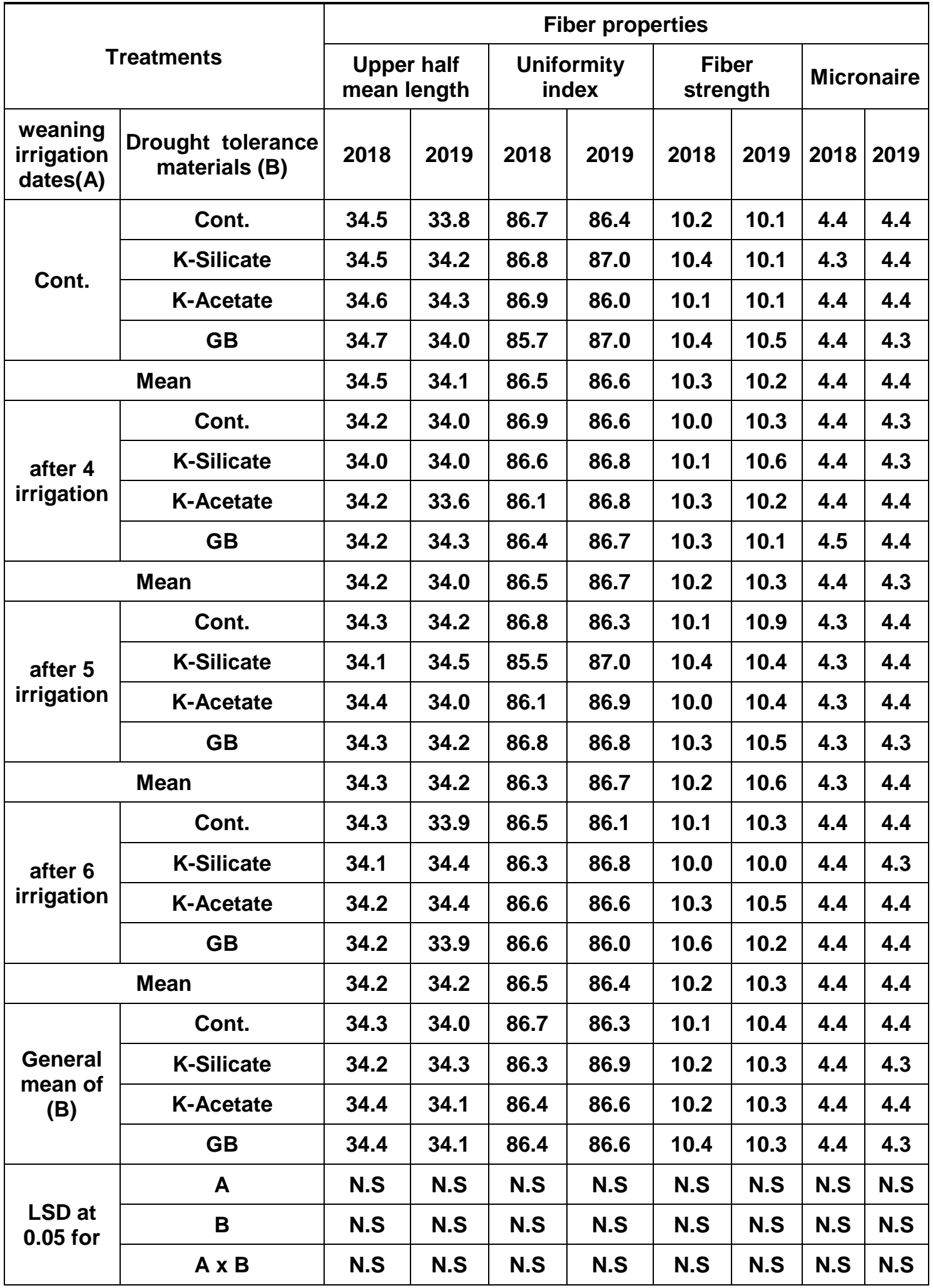


1- Effect of weaning irrigation dates treatments on growth, earliness, yield and fiber quality:

Data in Table (3) showed that growth attributes (plant height and no.of fruiting branches/plant) and earliness parameters (first fruiting node, days to first flower, days to first open boll and earliness \%) were significantly affected by weaning irrigation dates treatments. Weaning irrigation after four irrigation from planting had significantly increased earliness $\%$ in both seasons. While, significantly decreased the days to first flower, days to first open boll in the both seasons compared with the other treatments. The reduction in plant growth (plant height at harvest and first fruiting node) in case of longer irrigation period could be in part due to limiting the plant ability to absorb nutrients needed for optimal growth and development of the plant (Reddi and Reddi, 1995 and Watson, 1952).

Results presented in Table (4) indicate that weaning irrigation dates had significant effect on no. of open bolls/plant, boll weight and seed cotton yield/fed. while, were insignificantly affected seed index and lint \% in both seasons. Similar results were obtained by Makram and Abo-Nour (1995), AbdelMalak and Makram (1996), Ali et al., (1997) and Tennakoon and Milroy (2003).

Also data in Table (5) indicate that weaning irrigation dates treatments did not exhibit significant effect on all fiber properties in both seasons. Similar results were obtained byAbdel-Aal (1996).

2- Effect of spray dry materials treatments on growth, earliness, yield and fiber quality:

Data in Table (3) showed that spraying with drought tolerance materials treatments had a significant effect on plant height in both seasons, while did not exhibit significant effect on first fruiting node, days to first flower, days to first open boll and earliness $\%$.

Results presented in Table (4) indicate that yield and yield components traits were significantly affected by spraying with drought tolerance materials treatments except seed index and lint \% in both seasons. Spraying with Glycine betaine significantly increased no. of open bolls/plant, boll weight, and seed cotton yield/fed. Similar results were obtained by Agboma et al., (1997), Alia (2003) and Alia and Emara (2008).

The spraying with drought tolerance materials treatments did not exhibit any significant effect on all fiber properties under study in both seasons (Table 5).

3- Effect of the interaction between weaning irrigation dates and spraying with drought tolerance materials on growth, earliness, yield and fiber quality:

Data in Table (3) showed that the interaction between weaning irrigation dates and spraying with drought tolerance materials had a significant effect on earliness only in both seasons, while did not exhibit any significant effect on plant height, first fruiting node, days to first flower, days to first open boll.

Results presented in Table (4) indicate that yield and yield components traits were significantly affected by the interaction between weaning irrigation dates and spraying with drought tolerance materials treatments except seed index and lint \% in both seasons.

The interaction between weaning irrigation dates and spraying with drought tolerance materials did not exhibit any significant effect on all fiber properties under study in both seasons (Table 5). 
This may be attributed to the realization that these characteristics were less affected by the environmental factors.

\section{CONCLUSION}

The results obtained in this study concluded that using weaning irrigation after six irrigation from planting and spraying with Glycine betaine at 600 $\mathrm{g} / \mathrm{fed}$. gave high productivity of cotton Giza 94.

\section{REFERENCES}

A.S.T.M. (1986). American Society Testing and Materials. D4605, Vol.7, No.1, Easton, MD, USA.

Abdel-Aal, Amal, S. and M.A. Emara. (2014). Effect of Mohayat and weaning irrigation dates on growth and productivity of new hybrid cotton (Giza $86 \times 10229$ ). Egypt. J. of Appl. Sci., 29 (11): $573-584$.

Abdel-Aal, S.A. (1996). The optimum flowering stage to apply the last irrigation in cotton for Giza 77 cultivar. J. Agric. Res., Tanta Univ., 22(4): 507 511.

Abdel-Malak, K. and E. Makram (1996). The last irrigation in relation with flowering stage for early and late sowing for cotton cultivar Giza 83. Assiut J. Agric. Sci., 26(1): 147-153.

Abou-Zaid, M.K., M.A. Emara and S.A.F. Hamoda (2013). Effect of humex and bio-fertilization on growth, yield and quality of cotton under calcareous soil conditions. The $2^{\text {nd }}$ Alexandria International Cotton Conference, Faculty of Agric., SabaBasha, Alexandria, Univ., Alex. 10 - 11 April, 2013, Vol. (1): 12 - 21.

Agboma, M., M. Jones, P. PettonenSainio, H. Rita and E. Peha (1997). Exogenous glycine betaine enhances grain yield of maize, sorghum and wheat grown under two supplementary watering regimes. J. Agron., and Crop Sci., 178: 29-37.

Ali, S.A., M.A. El-Biely and E.A. Makram (1997). Flowering stage as a guide supplying for last irrigation in cotton for early and late sowing. Egypt. J. Appl. Sci., 12(2): 132 - 136.

Alia, A.M. Namich and M.A. Emara (2008). Response of cotton cultivar Giza 86 to application of glycine betaine under drought conditions. Proc. 17th Intern. Symp. of CIEC, 24-27 Nov. 2008 @ NRC (Micronutrient Project), Cairo - Egypt, pp. 97-107.

Alia, A. M. Namich. (2003). Effect of glycine betaine on growth, yield, yield components and some chemical constituents of cotton plant of Giza 80. Egypt. J. Appl. Sci., 18 (1): 91-101.

Basbag, S. (2008). Effects of humic acid application on yield and quality of cotton. Asian J. of Chemistry. 20(3): 1961 - 1966.

CSD Extension and Development Team (2010). Germinating ideas. The Australian Cottongrower, FEBRUARYMARCH, pp: 50 - 51.

Emara, M.A. (2014). Effect of some sources of potassium fertilizers on cotton production under calcareous soil conditions. Egypt. J. of Appl. Sci., 29 (11): $597-622$.

Freed, R.D. (1991). M Stat-C Microcomputer Statistical Program. Michigan State Univ., East Lansing, Michigan, USA.

Gomaa, M.A., F.I. Radwan, I.A. Ibrahim, M.A. Emara and A.A. Kattosh. (2014). Response of Egyptian cotton to soil and foliar potassium application under calcareous soil conditions. J. Adv. Agric. Res., Fac. Agric. (SabaBasha), 19(2): 236 - 246.

Gorham and Jokinen. (1998). Glycine betaine treatment improves cotton yield in field trials in Pakistan. P. 329. 
World cotton conference II, Athens, Greece, in Press.

Makram, E.A. and M.Sh. Abo-Nour (1995). The effective stage of flowering to apply last irrigation in cotton for early and late sowings (cultivar Giza 80). Proc. Beltwide Cotton Conferences (47 January). San Antonio Texas, USA. pp: $1358-1359$.

Meek, C., D. Oosterhis and J. Gorham (2003). Does foliar applied glycine betaine effect endogenous betaine levels and yield in cotton on line. Crop Management Doi, 10-904/CM-20030804-02-RS.

Morteza, M., A. Slaton, E. Evans and M. Fred (2005). Effect of potassium fertilization on cotton yield and petiole potassium. Summaries of Arkansas Cotton Res., pp: 74 - 78.

Ray, H.E. and J.R. Hazlitt (1960). Growing short staple cotton in Yuma Country. Cooperative Extension Service, Univ. Arizona, Circular 375, P: 9.

Reddi, G.H. and T.Y. Reddi (1995). Irrigation of Principal crops in efficient use of irrigation water. $r^{\text {nd }} E d$. Kalyani Pub., New Delhi. pp. 229 - 259.

Sawires, E.M.S. (1976). Effect of planting dates, plant density and number of irrigations on growth, yield fiber and yarn properties. M.Sc. Thesis, Ain Shams Univ., pp: $158-167$.

Snedecor and Cochran (1988). Statistical Methods. $7^{\text {th }}$ Ed. Press, lowa, Ames, pp: $225-269$.

Temz, M., E. Karahanand Y. Koca (2009). Effects of humic substances on cotton. Asian J. of Chemistry, 21(3): 1983 - 1989.

Tennakoon, S.B. and S.P. Milroy (2003). Crop water use and water use efficiency on irrigated cotton farms in Australia. Agricultural Water Management, (61)3: 179 - 194.

Watson, D.J. (1952). The physiological basis of variation in yield. Advances in Agron., 4: 101 - 145. 
تأثير ميعاد رية الفطام ورش مواد لتحمل الجفاف على نمو وإنتاجية

\section{صنف القطن جيزة ؟}

مصطفى عطية عمارة، أمل سامى عبد العال، الاسوقي الاسوقي ديشيش

قسم بحوث المعاملات الزراعية - معهد بحوث القطن - مركز البحوث الزراعية - الجيزة - مصر.

الملخص العربي

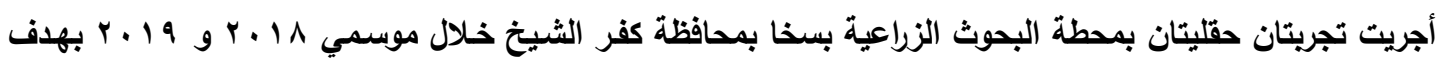

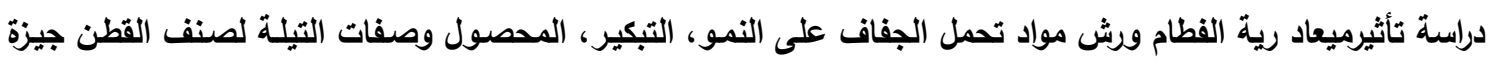

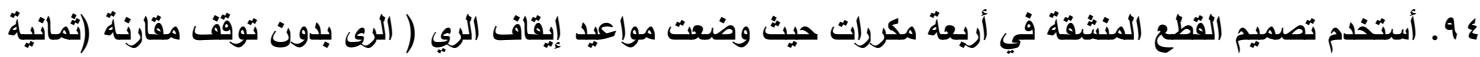
ريات )، بعد أريع ريات، بعد خمس ريات ويعد ست ريات) فى القطع الرئيسية ووضعت مواد الرش لتحمل الجفاف (بدون رش، رش سيليكات بوتاسيوم، رش أسيتات بوتاسيوم ورش جلسين بتات بتاين) فى القطع المنثقة. وتتلخص أهم النتائج المتحصل عليها فئيما يلئى

1) أدى الفطام بعد أريع ريات الى زيادة معنوية لصفة نسبة التبكير بالمقارنة بباقي المعاملات في حين أنه لم يكن لـه أي

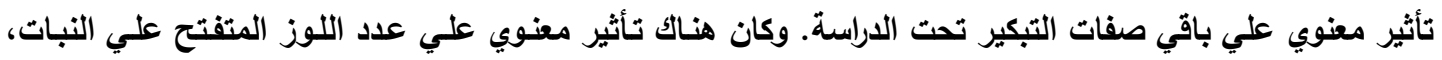
متوسط وزن اللوزة ومحصول القطن الزهر/فدان، ولم يكن هناك أي تأثير معنوي علي تصافي الحليج أو معامل البذرة

$$
\text { في كلا الموسمين تحت الدراسة. }
$$

Y) أدى الرش بمواد تحمل الجفاف (جليسين بتاين) الى نقص معنوي فى ارتفاع النباتات عند الحصاد مقارنة بمواد الرش فئ

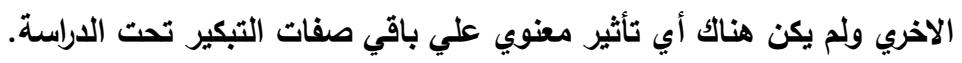

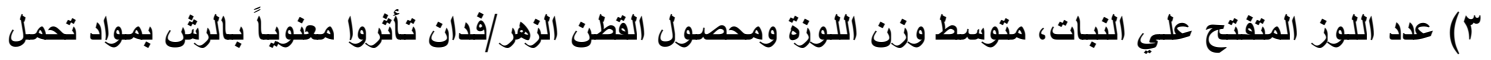
الجفاف في كلا الموسمين تحت الدراسة وذلك لصالح الرش بالجليسين بتاين مقارنة بمواد الرش الثرن الاخري. ؛ ) لم تؤثر معاملات إيقاف الري والرش بمواد تحمل الجفاف والتفاعل بينهم على صفات التيلة المدروسة.

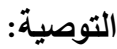

من النتائج المتحصل عليها يكن التوصية بإيقاف الري بعد ست ريات من الزراعة مـع رش مـادة الجليسين بتاين بمعدل . . 1 جرام/فدان وذلك لزيادة إنتاجية الصنف جيزة ؛ 9 تحت ظروف منطقة سخا بكفر الثيخ.

السادة المحكمين

أ.د/ وجدى محمد الثاذلى مركز البحوث الزراعية

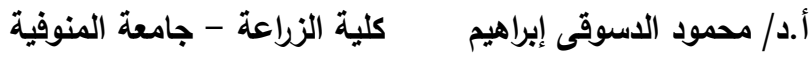

